\title{
PENGARUH LAMA FERMENTASI AMPAS PUTAK (Corypha gebanga) TERHADAP KUALITAS FISIK DAN KUALITAS KIMIA MENGGUNAKAN Aspergillus oryzae
}

\author{
Effect of Fermentation Time of Putak Dregs (Corypha gebanga) to The Physical \\ and Chemical Quality Using Aspergillus oryzae \\ Asih Yuliana ${ }^{1)}$, Siti Chuzaemi ${ }^{2}$ \\ ${ }^{1)}$ Mahasiswa Fakultas Peternakan, Universitas Brawijaya Jalan Veteran, Ketawanggede, Kec. Lowokwaru, \\ Kota Malang, Jawa Timur 65145 \\ ${ }^{2)}$ Dosen Fakultas Peternakan, Universitas Brawijaya Jalan Veteran, Ketawanggede, Kec. Lowokwaru, Kota \\ Malang, Jawa Timur 65145 \\ E-mail: Asihyuliana055@gmail.com
}

\begin{abstract}
ABSTRAK
Penelitian ini bertujuan untuk mengetahui pengaruh lama fermentasi yang berbeda pada ampas putak (Corypha gebanga) menggunakan Aspergillus oryzae terhadap nilai pH, warna, aroma, tekstur, bahan kering (BK), bahan organik (BO), protein kasar (PK) dan serat kasar (SK). Metode penelitian yang digunakan dalam penelitian ini adalah percobaan laboratorium dengan menggunakan Rancangan Acak Lengkap (RAL) 5 perlakuan dan 5 kali ulangan. Perlakuan terdiri dari PO (ampas putak tanpa fermentasi), P1 (ampas putak + Aspergillus oryzae 0,9\% difermentasi 24 jam), P2 (ampas putak + Aspergillus oryzae 0,9\% difermentasi 48 jam), P3 (ampas putak + Aspergillus oryzae 0,9\% difermentasi 72 jam), P4 (ampas putak + Aspergillus oryzae 0,9\% difermentasi 96 jam). Data dianalisis dengan menggunakan metode analysis of variance (ANOVA) dan dilanjutkan dengan Uji Jarak Berganda Duncan. Hasil penelitian terhadap nilai warna P0, P1, P2, P3, dan P4 berturut-turut yaitu (4,00; 2,68; 2,66; 1,74; dan 1,60). Hasil nilai aroma P0, P1, P2, P3, dan P4 berturut-turut yaitu (1,00; 2,98; 2,96; 2,54; dan 2,08). Hasil nilai tekstur P0, P1, P2, P3, dan P4 berturut-turut yaitu (1,00; 3,00; 3,38; 3,62; dan 3,64). Kandungan BK tertinggi pada P0 yaitu 87,29\% disusul oleh P1 (46,18\%), P2 (38,44\%), P3 (33,06\%) dan P4 (27,75\%). Kandungan BO tertinggi pada perlakuan P0 yaitu 94,73\% disusul oleh P1 (92,45\%), P2 (89,91\%), P3 (88,19\%) dan P4 (86,72\%). Kandungan PK tertinggi pada perlakuan P4 yaitu 27,04\% disusul oleh P3 (24,08\%), P2 (21,20\%), P1 (16,05\%) dan PO (2,31\%). Kandungan SK terendah pada P0 yaitu 7,38\% disusul oleh P1 (8,59\%), P2 (15,14\%), P3 (19,22\%) dan terjadi penurunan pada perlakuan P4 yaitu 17,28\%. Berdasarkan hasil penelitian dapat disimpulkan bahwa hasil yang terbaik ditinjau dari peningkatan kualitas fisik, $P K, S K$ dan penurunan $\mathrm{pH}, \mathrm{BK}, \mathrm{BO}$ yaitu dengan fermentasi ampas putak selama 96 jam dengan menggunakan Aspergillus oryzae sebanyak $0,9 \%$.
\end{abstract}

Kata kunci: Ampas putak, aspergillus oryzae, kualitas fisik, kualitas kimia 


\begin{abstract}
The purpose of research was to determine the effect of differences incubation time on putak dregs (Corypha gebanga) using Aspergillus oryzae to $\mathrm{pH}$ value, colour, aroma, texture, dry matter (DM), organic matter (OM), crude protein $(C P)$, and crude fiber $(C F)$. The method of this research was experimental method by used Completely Randomized Design with 5 treatments and 5 replications. The treatment consisted of PO (non-fermentation putak dregs), P1 (putak dregs + Aspergillus oryzae 0,9\% fermentation 24 hours), P2 (putak dregs + Aspergillus oryzae 0,9\% fermentation 48 hours), P3 (putak dregs + Aspergillus oryzae 0,9\% fermentation 72 hours), P4 (putak dregs + Aspergillus oryzae 0,9\% fermentation 96 hours). The data were analyzed using ANOVA (Analysis of Variance) and followed with Duncan's Multiple Range Test if there was significant effect. The results of the color values P0, P1, P2, $P 3$, and $P 4$, respectively $(4.00 ; 2.68 ; 2.66 ; 1.74 ;$ and 1.60$)$. The results of the aroma value $P 0$, $P 1, P 2, P 3$, and $P 4$, respectively $(1.00 ; 2.98 ; 2.96 ; 2.54$; and 2.08$)$. The results of texture values $P 0, P 1, P 2, P 3$, and $P 4$ are $(1.00 ; 3.00 ; 3.38 ; 3.62$; and 3.64) respectively. The highest DM content at P0 was $87.29 \%$ followed by P1 (46.18\%), P2 (38.44\%), P3 (33.06\%) and P4 (27.75\%). The highest OM content in treatment $P 0$ was $94.73 \%$ followed by $P 1$ (92.45\%), P2 (89.91\%), P3 (88.19\%) and P4 (86.72\%). The highest CP content in P4 treatment was $27.04 \%$ followed by $P 3$ (24.08\%), P2 (21.20\%), P1 (16.05\%) and PO (2.31\%). The lowest CF content at P0 is $7.38 \%$ followed by P1 (8.59\%), P2 (15.14\%), P3 (19.22\%) and a decrease in P4 treatment which is $17.28 \%$. Based on the result, it can be concluded that the best treatment reviewed from the increasing physical quality, $C P, C F$, and decreasing of $p H$ value, $D M$, and OM were obtained by incubation time of putak dregs in 96 hours with Aspergillus oryzae.
\end{abstract}

Key word: Putak dregs, aspergillus oryzae, chemical quality, physical quality

How to Cite :

Yuliana, A., \& Chuzaemi, S. (2019). Pengaruh Lama Fermentasi Ampas Putak (Corypha gebanga) Terhadap Kualitas Fisik Dan Kualitas Kimia Menggunakan Aspergillus oryzae. Jurnal Nutrisi Ternak Tropis 2 (1) 19-32
*Corresponding author :

Asih Yuliana

Email : Asihyuliana055@gmail.com

Fakultas Peternakan, Universitas Brawijaya Jalan Veteran, Ketawanggede, Kec. Lowokwaru, Kota Malang, Jawa Timur 65145 


\section{PENDAHULUAN}

Pakan yang baik merupakan pakan yang mampu memenuhi kebutuhan nutrisi ternak. Permasalahan yang timbul selain kandungan nutrien pakan, ketersediaan bahan pakan yang rendah dan harga pakan yang cukup tinggi bersaing dengan harga pangan manusia. Menurut Rohmawati, Djunaidi dan Widodo (2015), rendahnya ketersediaan sumber pakan dengan harga yang tinggi menjadi kendala dalam upaya pengembangan dan peningkatan usaha peternakan. Harga pakan yang tinggi di Indonesia merupakan permasalahan umum dalam usaha peternakan yang belum mendapatkan solusinya. Biaya produksi terbesar adalah pakan yaitu sekitar $70 \%$. Berfluktuasinya ketersediaan dan harga bahan pakan perlu dilakukan pakan alternatif yang pemanfaatannya tidak bersaing dengan manusia.

Pohon Gewang atau gebang (Corypha gebanga) merupakan nama dari sejenis palma tinggi yang tumbuh di daerah dataran rendah. Tumbuhan ini di Indonesia banyak ditemukan di Nusa Tenggara Timur (NTT) (Anonimous, 2017). Tumbuhan sagu memiliki sekitar 60 varietas yang tersebar di wilayah seluas 900.000 ha tanah (Fuah and Pattie, 2014). Empulur batang pohon Gewang di Pulau Timor, NTT merupakan asal dari putak yang digunakan sebagai pangan penduduk setempat. Ampas putak adalah hasil samping dari putak yang memiliki potensi cukup besar karena ketersediaannya yang melimpah dan pemanfaatannya belum maksimal.

Satu pohon gewang dengan tinggi 13 m dapat menghasilkan $396 \mathrm{~kg}$ berat kering atau $663 \pm 124 \mathrm{~kg}$ putak segar. Ampas putak yang dihasilkan dari putak yaitu sekitar 50\% dari $396 \mathrm{~kg}$ berat kering. Hasil penelitian Soares (2018) terhadap kandungan ampas putak yaitu BK 86,84\%, abu 3,88\%, PK $2,3 \%$, LK $0,46 \%$ dan SK 5,26\%. Perlu adanya proses pengolahan untuk meningkatkan kandungan nutrisi ampas putak agar pemanfaatannya sebagai pakan lebih optimal. Salah satu metode yang dapat digunakan untuk meningkatkan kandungan nutrisi bahan pakan adalah melalui fermentasi.

Fermentasi adalah salah satu metode yang digunakan untuk meningkatkan kualitas dari bahan pakan ternak. Semakin lama waktu fermentasi semakin banyak zatzat yang dapat dirombak, sebaliknya semakin banyak level inokulum yang diberikan maka semakin cepat fermentasi berlangsung (Martaguri, Mirnawati dan Muis, 2011). Mikroorganisme yang digunakan dalam proses fermentasi ampas putak ini adalah Aspergillus oryzae yang dilakukan dengan waktu fermentasi yang berbeda guna mengetahui waktu yang optimum untuk mendapatkan kandungan nutrisi ampas putak baik yang ditinjau dari $\mathrm{pH}$, warna, aroma, tekstur, bahan kering, bahan organik, protein kasar dan serat kasar.

\section{MATERI DAN METODE}

\section{Materi Penelitian}

Ampas Putak (Corypha gebanga), Aspergillus oryzae, $\mathrm{KH}_{2} \mathrm{PO}_{4},\left(\mathrm{NH}_{4}\right)_{2} \mathrm{SO}_{4}$, dan Urea.

\section{Metode Penelitian}

Metode penelitian adalah percobaan di laboratorium dengan menggunakan Rancangan Acak Lengkap (RAL) 5 perlakuan dan 5 kali ulangan. Perlakuan yang dilakukan dalam penelitian ini adalah sebagai berikut :

$$
\begin{aligned}
\mathrm{P}_{0}= & \text { Ampas putak tanpa fermentasi } \\
\mathrm{P}_{1}= & \text { Ampas putak }+ \text { Aspergillus oryzae } \\
& 0,9 \% \text { (fermentasi } 24 \text { jam) } \\
\mathrm{P}_{2}= & \text { Ampas putak }+ \text { Aspergillus oryzae } \\
& 0,9 \% \text { (fermentasi } 48 \text { jam) } \\
\mathrm{P}_{3}= & \text { Ampas putak }+ \text { Aspergillus oryzae } \\
& 0,9 \% \text { (fermentasi } 72 \text { jam) } \\
\mathrm{P}_{4}= & \text { Ampas putak }+ \text { Aspergillus oryzae } \\
& 0,9 \% \text { (fermentasi } 96 \text { jam) }
\end{aligned}
$$




\section{Prosedur Pembuatan Fermentasi Ampas Putak}

1. Ampas putak kering sebanyak $100 \mathrm{~g}$ dimasukkan ke dalam plastik tahan panas (Hilakore dkk., 2013). Hal ini dilakukan sebanyak perlakuan.

2. Mineral $\mathrm{KH}_{2} \mathrm{PO}_{4} 2 \mathrm{~g}$, $\left(\mathrm{NH}_{4}\right)_{2} \mathrm{SO}_{4} 4,62 \mathrm{~g}$ dan urea $3,15 \mathrm{~g}$ dicampur dengan air hingga $100 \mathrm{ml}$.

3. Ditambahkan kedalam ampas putak dan dikukus selama 30 menit, setelah itu didinginkan (Hilakore dkk., 2013).

4. Ditambahkan inokulum Aspergillus oryzae $\quad 0,9 \% \quad$ (Susanti, 2015), difermentasikan secara semi aerob dengan lama fermentasi sesuai perlakuan 24, 48, 72, dan 96 jam.

5. Dikeringkan (suhu $60^{\circ} \mathrm{C}$ ) untuk digunakan sebagai sampel dalam uji bahan kering, bahan organik, protein kasar dan serat kasar.

Variabel yang diamati terdiri atas:

Variabel yang diamati untuk mengetahui keberhasilan dalam penelitian ini adalah $\mathrm{pH}$, warna, aroma, tekstur, bahan kering, bahan organik, protein kasar, dan serat kasar.

\section{Analisis Data}

Data yang diperoleh dianalisis statistik menggunakan analisis ragam (ANOVA) dari Rancangan Acak Lengkap (RAL). Selanjutnya untuk mengetahui perbedaan antar perlakuan dilakukan dengan menggunakan Uji Jarak Berganda Duncan (Steel dan Torrie, 2003).

\section{HASIL DAN PEMBAHASAN}

\section{Kualitas Fisik Fermentasi Ampas Putak}

Hasil analisis $\mathrm{pH}$ fermentasi ampas putak ditampilkan pada Tabel 1. hasil analisis warna, aroma dan tekstur fermentasi ampas putak ditampilkan pada Tabel 2.

\section{Pengaruh perlakuan terhadap nilai $\mathbf{p H}$}

Hasil analisis statistik pada Tabel 1 . menunjukkan bahwa perlakuan fermentasi yang bervariasi memberikan hasil berbeda sangat nyata $(\mathrm{P} \leq 0,01)$ terhadap nilai $\mathrm{pH}$ fermentasi ampas putak. Berdasarkan hasil Uji Jarak Berganda Duncan, diketahui bahwa nilai $\mathrm{pH}$ tertinggi adalah perlakuan $\mathrm{P}_{0}$ berbeda sangat nyata $(\mathrm{P} \leq 0,01)$ dibandingkan perlakuan lainnya dan nilai $\mathrm{pH}$ terendah adalah perlakuan $\mathrm{P}_{2}$. Perlakuan $\mathrm{P}_{2}$ berbeda sangat nyata $(P \leq 0,01)$ dibandingkan dengan perlakuan $\mathrm{P}_{0}, \mathrm{P}_{1}$ dan $\mathrm{P}_{4}$, tetapi tidak ada perbedaan yang sangat nyata $(\mathrm{P} \leq 0,01)$ terhadap perlakuan $\mathrm{P}_{3}$. Perlakuan $\mathrm{P}_{0}$ tanpa fermentasi memiliki nilai $\mathrm{pH}$ tertinggi sebesar $(7,00)$, sedangkan perlakuan $\mathrm{P}_{2}$ dengan lama fermentasi 48 jam memiliki nilai $\mathrm{pH}$ terendah sebesar $(4,46)$.

Tabel 1. Pengaruh Perlakuan Fermentasi Pada Nilai pH Fermentasi Ampas Putak.

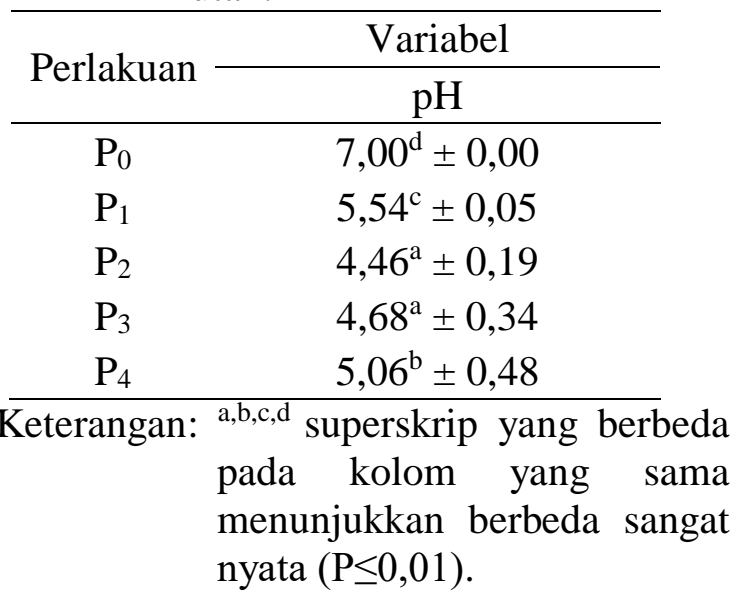

Tabel 2. Pengaruh Perlakuan Fermentasi Pada Analisis Fisik Fermentasi Ampas Putak.

\begin{tabular}{cccc}
\hline \multirow{3}{*}{$\begin{array}{c}\text { Perla } \\
\text { Kuan }\end{array}$} & Warna & Aroma & Tekstur \\
\cline { 2 - 4 } & & & \\
\hline \multirow{2}{*}{$\mathrm{P}_{0}$} & $4,00^{\mathrm{b}} \pm$ & $1,00^{\mathrm{a}} \pm$ & $1,00^{\mathrm{a}} \pm$ \\
& 0,00 & 0,00 & 0,00 \\
$\mathrm{P}_{1}$ & $2,68^{\mathrm{a}} \pm$ & $2,98^{\mathrm{d}} \pm$ & $3,00^{\mathrm{b}} \pm$ \\
& 0,47 & 0,25 & 0,00 \\
$\mathrm{P}_{2}$ & $2,66^{\mathrm{a}} \pm$ & $2,96^{\mathrm{d}} \pm$ & $3,38^{\mathrm{c}} \pm$ \\
& 0,48 & 0,86 & 0,53 \\
$\mathrm{P}_{3}$ & $1,74^{\mathrm{a}} \pm$ & $2,54^{\mathrm{c}} \pm$ & $3,62^{\mathrm{d}} \pm$ \\
& 0,44 & 0,76 & 0,60 \\
$\mathrm{P}_{4}$ & $1,60^{\mathrm{a}} \pm$ & $2,08^{\mathrm{b}} \pm$ & $3,64^{\mathrm{d}} \pm$ \\
& 0,49 & 0,27 & 0,48 \\
\hline
\end{tabular}

Keterangan: ${ }^{\mathrm{a}, \mathrm{b}, \mathrm{c}, \mathrm{d}}$ superskrip yang berbeda pada kolom yang sama menunjukkan berbeda sangat nyata $(\mathrm{P} \leq 0,01)$. 
Hasil analisis nilai $\mathrm{pH}$ menunjukkan bahwa selama fermentasi terjadi penurunan nilai $\mathrm{pH}$ sampai hari kedua dan mulai terjadi peningkatan sedikit demi sedikit sampai hari keempat. Hal ini sesuai dengan pendapat Yumas dan Rosniati (2014) selama fermentasi mula-mula terjadi penurunan derajat keasaman $(\mathrm{pH})$ sampai hari ketiga dan terjadi peningkatan sedikit demi sedikit sampai hari kelima. Setelah fermentasi tiga hari yaitu fase penyesuaian terjadi penurunan nilai $\mathrm{pH}$, hal ini karena adanya aktivitas yeast yang akan menyesuaikan diri dengan lingkungan sekitarnya sehingga menghasilkan enzim yang akan digunakan untuk merombak gula menjadi alkohol. Aspergillus oryzae mengalami pertumbuhan optimum pada pH 4,5 (Jayanti dkk., 2013). Gozan dkk., (2007) juga berpendapat bahwa hari ketiga fermentasi yeast berada pada fase penyesuaian diri dengan lingkungan agar tetap hidup, sehingga belum berada pada fase eksponensial. Menurut Sardjono (2008), fase pertumbuhan Aspergillus oryzae yaitu hari pertama merupakan fase adaptasi, sehingga pada perlakuan $\mathrm{P}_{2}$ (fermentasi 24 jam) terjadi penurunan $\mathrm{pH}$.

Hari ketiga adalah fase eksponensial yang ditandai dengan kenaikan massa sel dari Aspergillus oryzae secara signifikan. Keadaan ini mengidentifikasikan bahwa pada range waktu tersebut Aspergillus oryzae membelah dengan cepat, sehingga pada perlakuan $\mathrm{P}_{3}$ (fermentasi 3 hari) sudah mulai terjadi kenaikan nilai $\mathrm{pH}$ dari perlakuan $\mathrm{P}_{2}$ (fermentasi 2 hari) 4,46 menjadi 4,68.

Berbeda dengan pendapat Jayanti dkk (2013), fase pertumbuhan Aspergillus oryzae hari pertama merupakan fase adaptasi. Hari kesembilan adalah fase eksponensial yang ditandai dengan banyaknya massa sel Aspergillus oryzae secara signifikan, yang berarti menunjukkan bahwa pada range waktu tersebut terjadi kecepatan pembelahan Aspergillus oryzae.

\section{Pengaruh perlakuan terhadap warna}

Hasil analisis statistik pada Tabel 2. menunjukkan bahwa perlakuan fermentasi yang bervariasi memberikan hasil berbeda sangat nyata $(\mathrm{P} \leq 0,01)$ terhadap nilai warna fermentasi ampas putak. Hasil uji Jarak Berganda Duncan memberikan hasil bahwa nilai warna tertinggi adalah perlakuan $\mathrm{P}_{0}$ berbeda sangat nyata $(\mathrm{P} \leq 0,01)$ dibandingkan perlakuan $\mathrm{P}_{1}, \mathrm{P}_{2}, \mathrm{P}_{3}$, dan $\mathrm{P}_{4}$. Perlakuan fermentasi ampas putak secara berturutturut (0 jam, 24 jam, 48 jam, 72, dan 96 jam), semakin lama waktu fermentasi warna ampas putak fermentasi berubah menjadi cokelat kehijauan dari cokelat terang/cokelat muda. Keterangan kualitatif nilai warna yaitu 1 cokelat hijau kekuningan, 2 cokelat kehijauan, 3 cokelat, dan 4 cokelat muda/terang.

Lestari (2001) menyatakan bahwa terjadinya fermentasi selain mengawetkan juga dapat menghasilkan warna yang diinginkan. Ampas putak tanpa fermentasi memiliki warna coklat terang, sehingga dilihat dari nilai warna ampas putak fermentasi yang diperoleh, perlakuan $\mathrm{P}_{1}$ (fermentasi 24 jam) dan $\mathrm{P}_{2}$ (fermentasi 48 jam) berturut-turut 2,68 dan 2,66 hal ini cukup bagus karena memiliki warna cokelat yang masih mendekati warna ampas putak tanpa fermentasi.

Sesuai dengan pendapat Abdelha et al., (2005), fermentasi yang baik memiliki warna yang tidak jauh berbeda dengan warna bahan bakunya serta memiliki $\mathrm{pH}$ rendah dan beraroma asam. Hasil penelitian Herliani dkk (2014) selama satu minggu terhadap warna dedak fermentasi dengan perlakuan kontrol tidak menunjukkan hasil yang berbeda. Warna cokelat diperoleh pada semua perlakuan, namun ada sedikit perubahan pada perlakuan DF3.

Perubahan warna cokelat menjadi sedikit putih disebabkan adanya pertumbuhan jamur dalam jumlah yang sedikit. Warna ampas putak fermentasi perlakuan $\mathrm{P}_{3}$ dan $\mathrm{P}_{4}$ yang tampak cokelat kehijauan disebabkan karena adanya pertumbuhan koloni dari jamur yang digunakan untuk fermentasi ampas putak. Berdasarkan kurva pertumbuhan Aspergillus oryzae terjadi pertumbuhan spora yang pesat pada hari ketiga dan keempat (Sardjono, 2008). Menurut 
Oramahi (2006) Aspergillus oryzae memiliki koloni berwarna hijau kekuningan dan miselium berwarna putih. Hal ini didukung oleh pendapat Rihadini dkk., (2017) bahwa warna fermentasi tongkol jagung dengan Trichoderma harzianum yaitu hijau kekuningan. Perubahan warna hijau kekuningan tersebut merupakan efek dari penambahan starter Trichoderma harzianum, hal ini disebabkan karena adanya kumpulan konidia pada ujung hifa kapang tersebut.

\section{Pengaruh perlakuan terhadap aroma}

Berdasarkan hasil analisis statistik pada Tabel 2. menunjukkan bahwa perlakuan fermentasi yang bervariasi memberikan hasil berbeda sangat nyata $(\mathrm{P} \leq 0,01)$ terhadap nilai aroma fermentasi ampas putak. Berdasarkan hasil uji Jarak Berganda Duncan, maka diketahui bahwa perlakuan nilai terendah adalah perlakuan $\mathrm{P}_{0}$ yang berbeda sangat nyata $(\mathrm{P} \leq 0,01)$ dibandingkan perlakuan lainnya dan nilai tertinggi adalah perlakuan $\mathrm{P}_{1}$. Perlakuan $\mathrm{P}_{1}$ berbeda sangat nyata $(\mathrm{P} \leq 0,01)$ dibandingkan dengan perlakuan $\mathrm{P}_{0}, \mathrm{P}_{3}$ dan $\mathrm{P}_{4}$, tetapi tidak berbeda sangat nyata $(P \leq 0,01)$ terhadap perlakuan $\mathrm{P}_{2}$. Keterangan kualitatif nilai aroma yaitu 1 khas ampas putak, 2 apek, 3 asam, dan 4 manis.

Perlakuan $\mathrm{P}_{0}$ merupakan ampas putak tanpa fermentasi yang memiliki aroma apek. Winarno (2000) melaporkan bahwa fermentasi dapat menghasilkan aroma atau flavour yang lebih disukai dari pada bahan yang tidak difermentasi. Perlakuan $\mathrm{P}_{1}$ dan $\mathrm{P}_{2}$ dengan lama waktu fermentasi berturutturut 24 dan 48 jam memiliki bau asam dibandingkan perlakuan lainnya. Menurut Lamid dkk., (2012) fermentasi yang baik mempunyai bau asam karena mengandung asam laktat, bukan bau yang menyengat. Aroma asam fermentasi pakan disebabkan karena pada proses fermentasi terjadi penguraian nutrien khususnya karbohidrat menjadi asam organik. Terbentuknya asam pada waktu fermentasi menyebabkan $\mathrm{pH}$ turun, keadaan ini menghambat proses respirasi, proteolisis dan mencegah aktifnya bakteri (Kurnianingtyas dkk., 2012).
Perlakuan $\mathrm{P}_{3}$ dan $\mathrm{P}_{4}$ memiliki aroma apek yang mendekati aroma ampas putak tanpa fermentasi, hal ini diduga pada perlakuan $\mathrm{P}_{3}$ sudah mulai terjadi kenaikan nilai $\mathrm{pH}$. Menurut Yumas dan Rosniati (2014) selama fase penyesuaian terjadi penurunan nilai $\mathrm{pH}$ saat fermentasi dan terjadi peningkatan sedikit demi sedikit sampai hari kelima. Menurut Sardjono (2008), fase pertumbuhan Aspergillus oryzae yaitu hari pertama merupakan fase adaptasi, hari ketiga adalah fase eksponensial, sehingga pada perlakuan $\mathrm{P}_{3}$ dan $\mathrm{P}_{4}$ sudah tidak asam lagi.

\section{Pengaruh perlakuan terhadap tekstur}

Hasil analisis statistik pada Tabel 2. menunjukkan bahwa perlakuan fermentasi yang bervariasi memberikan hasil berbeda sangat nyata $(P \leq 0,01)$ terhadap nilai tekstur fermentasi ampas putak. Hasil uji Jarak Berganda Duncan memberikan hasil bahwa nilai tekstur terendah adalah perlakuan $\mathrm{P}_{0}$ yang berbeda sangat nyata $(\mathrm{P} \leq 0,01)$ dibandingkan perlakuan lainnya. Nilai tekstur tertinggi dalam perlakuan adalah perlakuan $\mathrm{P}_{4}$ yang memberikan hasil berbeda sangat nyata $(\mathrm{P} \leq 0,01)$ dibandingkan perlakuan $\mathrm{P}_{0}, \mathrm{P}_{1}$ dan $\mathrm{P}_{2}$, sedangkan perlakuan $\mathrm{P}_{4}$ tidak berbeda sangat nyata $(\mathrm{P} \leq 0,01)$ terhadap perlakuan $\mathrm{P}_{3}$. Teskstur ampas putak fermentasi terlihat adanya perubahan tekstur apabila dibandingkan dengan perlakuan $\mathrm{P}_{0}$.

Semakin lama waktu fermentasi ampas putak fermentasi memiliki tekstur lunak. Menurut Sariri dkk., (2011) menyatakan bahwa tanda fermentasi pakan kering yang telah berhasil yaitu terjadi perubahan suhu yang meningkat, perubahan warna dan bau yang khas serta perubahan tekstur yang lebih lunak atau lapuk. Keterangan kualitatif nilai tekstur yaitu 1 halus, 2 kasar, 3 kenyal, dan 4 lunak. Terjadinya perubahan tekstur diduga ada kaitannya dengan kadar air disetiap ampas putak fermentasi. Hal ini didukung oleh hasil penelitian Kurniawan dkk., (2016) terhadap tekstur ampas kelapa sebelum dan sesudah dikukus mengalami perubahan karena pengukusan menyebabkan pelebaran 
pori-pori ampas kelapa sehingga kadar air meningkat dan tekstur menjadi lembut. Menurut hasil penelitian Julendra dkk., (2007) terhadap tekstur pakan yang mengandung onggok fermentasi $25 \%$ sedikit menggumpal dan pakan yang mengandung onggok fermentasi $30 \%$ menggumpal, kemungkinan disebabkan oleh kandungan kadar air yang lebih tinggi. Kenaikan kadar air selama penyimpanan dikarenakan partikel bahan pakan menyerap uap air dari udara, sehingga menyebabkan pertumbuhan jamur semakin meningkat karena bertambah banyak spora jamur dari udara terbawa masuk. Hal ini senada dengan Sukma dkk., (2010) bahwa peningkatan kadar air selama fermentasi disebabkan kapang yang diinokulasi pada bekatul melakukan aktivitas metabolisme yang mengeluarkan uap air, sehingga mempengaruhi kadar air pada bekatul.
Berdasarkan nilai tekstur fermentasi ampas putak, perlakuan $\mathrm{P}_{2}$ (fermentasi 48 jam) memiliki tekstur agak lunak sedangkan $\mathrm{P}_{3}$ (fermentasi 72 jam) dan $\mathrm{P}_{4}$ (fermentasi 96 jam) memiliki tekstur lunak, hal ini diduga karena hari kedua pada fase pertumbuhan Aspergillus oryzae merupakan fase adaptasi, hari ketiga merupakan fase eksponensial dan hari keempat merupakan fase stasioner yaitu masa dimana laju pertumbuhan bakteri menuju kematian sehingga jumlah bakteri secara keseluruhan tetap. Menurut Sardjono (2008), fase pertumbuhan Aspergillus oryzae yaitu hari pertama merupakan fase adaptasi, hari ketiga adalah fase eksponensial. Hari keempat merupakan fase stationer.

\section{Kualitas Kimia Fermentasi Ampas Putak}

Hasil analisis kandungan nutrien ampas putak dan fermentasi ampas putakd itampilkan pada Tabel 3.

Tabel 3. Kandungan Nutrien Ampas Putak dan Fermentasi Ampas Putak.

\begin{tabular}{ccccc}
\hline \multirow{2}{*}{ Perlakuan } & \multicolumn{4}{c}{ Variabel (\%) } \\
\cline { 2 - 5 } & BK & BO $^{*}$ & PK $^{*}$ & SK $^{*}$ \\
\hline P0 & $87,29^{\mathrm{e}} \pm 0,18$ & $94,73^{\mathrm{e}} \pm 0,18$ & $2,31^{\mathrm{a}} \pm 0,03$ & $7,38^{\mathrm{a}} \pm 0,35$ \\
P1 & $46,18^{\mathrm{d}} \pm 0,29$ & $92,45^{\mathrm{d}} \pm 0,22$ & $16,05^{\mathrm{b}} \pm 0,26$ & $8,59^{\mathrm{b}} \pm 0,37$ \\
P2 & $38,44^{\mathrm{c}} \pm 0,26$ & $89,91^{\mathrm{c}} \pm 0,14$ & $21,20^{\mathrm{c}} \pm 0,34$ & $15,14^{\mathrm{c}} \pm 0,47$ \\
P3 & $33,06^{\mathrm{b}} \pm 0,40$ & $88,19^{\mathrm{b}} \pm 0,31$ & $24,08^{\mathrm{d}} \pm 0,38$ & $19,22^{\mathrm{e}} \pm 0,34$ \\
P4 & $27,75^{\mathrm{a}} \pm 0,32$ & $86,72^{\mathrm{a}} \pm 0,29$ & $27,04^{\mathrm{e}} \pm 0,61$ & $17,28^{\mathrm{d}} \pm 0,36$ \\
\hline
\end{tabular}

Keterangan: ${ }^{\mathrm{a}, \mathrm{b}, \mathrm{c}, \mathrm{d}, \mathrm{e}}$ superskrip yang berbeda pada kolom yang sama menunjukkan berbeda sangat nyata $(\mathrm{P} \leq 0,01)$.

*Berdasarkan $100 \%$ BK

\section{Pengaruh Perlakuan Terhadap Kandungan Bahan Kering (BK)}

Hasil analisis statistik pada Tabel 3. menunjukkan bahwa perlakuan fermentasi yang bervariasi memberikan hasil berbeda sangat nyata $(\mathrm{P} \leq 0,01)$ terhadap kandungan bahan kering fermentasi ampas putak. Berdasarkan hasil uji Jarak Berganda Duncan, perlakuan $\mathrm{P}_{0}$ berbeda sangat nyata $(\mathrm{P} \leq 0,01)$ terhadap $\mathrm{P}_{1}, \mathrm{P}_{2}, \mathrm{P}_{3}$ dan $\mathrm{P}_{4}$. Perlakuan $\mathrm{P}_{0}$ ampas putak tanpa fermentasi memiliki kandungan BK tertinggi sebesar $87,29 \%$, sedangkan ampas putak setelah fermentasi yaitu perlakuan $\mathrm{P}_{4}$ dengan lama waktu fermentasi 96 jam memiliki kandungan BK terendah yaitu 27,75\%. Hal ini menunjukkan bahwa pada perlakuan ampas putak yang difermentasi yaitu semakin lama waktu fermentasi maka kandungan BK semakin menurun. Selain itu penurunan kandungan BK disebabkan karena adanya penambahan air pada proses pembuatan fermentasi ampas putak. Penurunan bahan kering diiringi dengan peningkatan kadar air.

Peningkatan kadar air ampas putak terjadi selama proses fermentasi karena penguraian bahan kering yang digunakan untuk sumber energi oleh Aspergillus oryzae sebagai inokulum sehingga terjadi 
penurunan bahan kering. Menurut Mirwandono dkk., (2006), kehilangan bahan kering yang terjadi selama proses fermentasi dikarenakan adanya perombakan bahan organik terutama karbohidrat yang digunakan sebagai sumber energi. Karbohidrat akan dipecah menjadi glukosa sampai terbentuk energi. Dinding sel kapang selama fermentasi akan mengalami pertumbuhan, semakin lama waktu fermentasi maka akan menghasilkan miselium yang semakin banyak. Menurut hasil penelitian Anggraeny dan Umiyasih (2009) bahwa kandungan bahan kering ampas pati aren hasil fermentasi menggunakan Saccharomyces cerevisiae menunjukkan adanya penurunan, saat fermentasi 0 jam ampas pati aren memiliki kandungan BK $31,57 \%$ sedangkan saat fermentasi 72 jam ampas pati aren memiliki kandungan BK 30,30\%.

Kandungan BK tertinggi perlakuan ampas putak yang difermentasi yaitu perlakuan $\mathrm{P}_{1}$ (fermentasi 24 jam) sebesar $46,18 \%$ karena fase pertumbuhan Aspergillus oryzae berada pada fase adaptasi dan terus mengalami pertumbuhan hingga mencapai fase eksponensial sampai fase stasioner. Kandungan bahan kering yang diperoleh berbanding terbalik dengan fase pertumbuhan Aspergillus oryzae, sehingga terjadi penurunan kandungan $\mathrm{BK}$ sampai hari keempat $\left(\mathrm{P}_{4}\right)$ hingga mencapai setengah persen nilai kandungan $\mathrm{BK}$ dari $\mathrm{P}_{1}$ yaitu $27,75 \%$. Hari keempat merupakan fase stasioner Aspergillus oryzae.

\section{Pengaruh perlakuan terhadap kandungan bahan organik (BO)}

Berdasarkan hasil analisis statistik pada Tabel 3. menunjukkan bahwa perlakuan fermentasi yang bervariasi memberikan hasil berbeda sangat nyata $(\mathrm{P} \leq 0,01)$ terhadap kandungan bahan organik fermentasi ampas putak. Hasil uji Jarak Berganda Duncan memberikan hasil bahwa kandungan bahan organik tertinggi adalah perlakuan $\mathrm{P}_{0}$ berbeda sangat nyata $(\mathrm{P} \leq 0,01)$ terhadap perlakuan $\mathrm{P}_{1}, \mathrm{P}_{2}, \mathrm{P}_{3}$, dan $\mathrm{P}_{4}$. Perlakuan $\mathrm{P}_{0}$ ampas putak tanpa fermentasi memiliki kandungan BO tertinggi sebesar
$94,73 \%$, sedangkan perlakuan $\mathrm{P}_{4}$ yaitu ampas putak fermentasi dengan lama waktu fermentasi 96 jam memiliki kandungan BO terendah yaitu $86,72 \%$. Semakin lama waktu fermentasi ampas putak secara berturutturut $(24,48,72$ dan 96 jam) menurunkan kandungan bahan organik ampas putak masing-masing sebesar $(92,45 \% ; 89,91 \%$; $88,19 \%$; dan $86,72 \%$ ).

Bahan organik yang ada dalam ampas putak dirombak oleh Aspergillus oryzae sebagai inokulum yang digunakan untuk memenuhi kebutuhan energi dalam pertumbuhannya. Menurut Hilakore (2008) menyatakan bahwa selama proses fermentasi akan terjadi kehilangan bahan organik, hal ini karena adanya perombakan bahan organik oleh enzim mikroba untuk memenuhi kebutuhan energi pada pertumbuhan kapang dan akan menghasilkan panas, air dan karbondioksida yang menyebabkan perubahan komposisi bahan. Hasil penelitian fermentasi putak menggunakan campuran Trichoderma reesei dan Aspergillus niger memperlihatkan bahwa level kultur dan lama fermentasi yang semakin tinggi mengakibatkan semakin banyak kehilangan BK dan BO.

Bahan organik yang tersedia dalam substrat akan dirombak oleh kapang dengan semakin panjangnya waktu fermentasi, sehingga perlakuan $\mathrm{P}_{4}$ (fermentasi 96 jam) memiliki kandungan $\mathrm{BO}$ paling rendah yaitu $86,72 \%$ dibanding dengan perlakuan $\mathrm{P}_{1}$ (fermentasi 24 jam). Berdasarkan fase pertumbuhan Aspergillus oryzae hari pertama merupakan fase adaptasi yang terus mengalami pertumbuhan hingga mencapai fase eksponensial sampai fase stasioner, sehingga perombakan $\mathrm{BO}$ oleh enzim mikroba untuk memenuhi kebutuhan energi pada pertumbuhan Aspergillus oryzae semakin besar yang menyebabkan nilai kandungan BO ampas putak semakin menurun.

Hal tersebut didukung oleh hasil penelitian Anggraeny dan Umiyasih (2009) terhadap ampas pati aren pada perlakuan fermentasi pendek (0 jam) memiliki BO 
yang lebih tinggi yaitu $92,67 \%$ dibanding dengan perlakuan fermentasi panjang (2472 jam) memiliki BO lebih rendah yaitu $89,92-92,64 \%$. Senyawa organik dari substrat akan didegradasi oleh mikroorganisme menjadi molekul yang lebih sederhana atau menjadi bentuk lain seperti air dan enegi untuk kebutuhan aktivitas mikroorganisme.

\section{Pengaruh perlakuan terhadap kandungan protein kasar (PK)}

Hasil analisis statistik pada Tabel 3. menunjukkan bahwa perlakuan fermentasi yang bervariasi memberikan hasil berbeda sangat nyata $(\mathrm{P} \leq 0,01)$ terhadap kandungan protein kasar fermentasi ampas putak. Berdasarkan hasil uji Jarak Berganda Duncan, maka diketahui bahwa kandungan protein kasar tertinggi adalah perlakuan $\mathrm{P}_{4}$ berbeda sangat nyata $(\mathrm{P} \leq 0,01)$ dibandingkan perlakuan lainnya dan kandungan protein kasar terendah adalah perlakuan $\mathrm{P}_{0}$. Perlakuan $\mathrm{P}_{0}$ berbeda sangat nyata $(\mathrm{P} \leq 0,01)$ terhadap perlakuan $\mathrm{P}_{1}, \mathrm{P}_{2}, \mathrm{P}_{3}$, dan $\mathrm{P}_{4}$.

Hasil analisis kandungan protein ampas putak setelah fermentasi mengalami peningkatan dibanding tanpa fermentasi. Semakin lama waktu fermentasi ampas putak berturut-turut ( 24 jam, 48 jam, 72 jam dan 96 jam) kandungan PK semakin meningkat masing-masing (16,05\%; $21,20 \%$; 24,08\%; dan 27,04\%). Peningkatan nilai PK disebabkan oleh waktu fermentasi, semakin lama waktu fermentasi maka produksi protein biomassa oleh Aspergillus oryzae semakin meningkat.

Pada grafik pertumbuhan dan produksi protein biomassa diketahui bahwa protein biomassa mengalami kenaikan sampai 5 hari fermentasi dan terus mengalami kenaikan walaupun tidak secara signifikan (Sardjono, 2008). Aspergillus oryzae dikenal sebagai kapang yang paling banyak menghasilkan enzim yaitu $\alpha$ amylase, $\alpha$-galaktosidase, glutaminase, protease dan $\beta$-glukosidase. Enzim yang paling penting adalah enzim protease dan amylase yang bekerja untuk memecah protein dan amilum dari substart (Susanti, 2015). Menurut Hastuti dkk., (2011) bahwa semakin lama waktu fermentasi maka kesempatan mikroba untuk melakukan pertumbuhan dan fermentasi semakin meningkat, sehingga jumlah mikroba semakin banyak dan akan menyebabkan peningkatan jumlah protein kasar.

Keadaan ini disebabkan karena semakin banyak jumlah mikroba maka produksi enzim protease semakin meningkat. Aktivitas enzim protease menyebabkan protein komplek yang bersifat tidak larut akan diubah menjadi protein yang bersifat larut dan akan mengalami kenaikan protein. Berdasarkan hasil penelitian Susanti (2015) terhadap fermentasi ampas kelapa menggunakan Aspergillus oryzae mampu meningkatkan nilai protein kasar hingga mencapai 8,63\% pada waktu fermentasi 96 jam, hal ini karena Aspergillus oryzae menghasilkan enzim protease yang mampu mendegradasi protein ampas kelapa menjadi asam amino, sehingga nitrogen terlarut meningkat dan nilai protein akan meningkat. Faktor meningkatnya kandungan PK hingga 13 kali dari nilai kandungan PK perlakuan $\mathrm{P}_{0}$ diduga karena adanya penambahan 3,15 gram urea pada fermentasi.

Urea mengandung 45\% N. Menurut Eko dkk., (2013) penambahan urea dengan level $0,5 \%$ sampai dengan $2 \%$ dapat meningkatkan nilai protein kasar 7,67\%$10,46 \%$. Hasil penelitian yang telah dilakukan terhadap padatan lumpur organik unit gas bio untuk perlakuan kontrol tanpa penambahan urea menunjukkan PK sebesar $7,67 \%$ dan perlakuan penambahan urea dengan level $0,5 \% ; 1 \% ; 1,5 \%$; dan $2 \%$ meningkatkan rataan $\mathrm{PK}$ berturut-turut $8,93 \%$; 9,03\%; 9,79\%; dan 10,46\%. Hal tersebut didukung oleh hasil penelitian Miskiyah dkk., (2006) bahwa kandungan PK ampas kelapa hasil fermentasi menggunakan Aspergillus niger dan penambahan $20 \mathrm{~g}$ urea mengalami peningkatan, ampas kelapa tanpa fermentasi memiliki kandungan PK 11,35\% sedangkan setelah difermentasi selama 2 hari mengalami peningkatan sebesar 26,09\%. Kandungan protein kasar ampas putak masih terus bertambah sampai fermentasi 
hari keempat masing-masing 16,05\%; $21,20 \%$; 24,08\%; dan 27,04\%. Peningkatan pertumbuhan kapang dalam medium menunjukkan meningkatnya kadar protein substrat.

Laju pertumbuhan lambat pada level kultur rendah yaitu ditandai dengan kenaikan kadar protein yang masih terus bertambah sampai fermentasi hari keempat. Rendahnya tingkat pemanfaatan nutrien yang tersedia diakibatkan karena rendahnya kepadatan kultur dalam medium, hal ini yang menyebabkan masih terjadinya pertumbuhan kapang sampai hari keempat. Sebaliknya dengan perlakuan kultur level yang cukup tinggi terjadi pertumbuhan yang cukup cepat untuk mencapai fase stasioner yang disebabkan karena ketersediaan nutrien yang mulai berkurang dan pertumbuhan terhenti karena akumulasi zatzat metabolik. Hal tersebut didukung oleh hasil penelitian Hilakore dkk., (2013) terhadap kandungan PK putak fermentasi pada pemberian kultur level rendah dan tinggi.

Kandungan PK dengan penambahan level Trichoderma reesei 5\% pada lama waktu fermentasi 2 hari, 3 hari, dan 4 hari masih terus bertambah sampai fermentasi hari keempat $(15,60 \% ; 16,45 \%$; dan 17,40\%). Kandungan PK dengan penambahan level Trichoderma reesei $10 \%$ pada lama waktu fermentasi 2, 3 dan 4 hari terjadi penambahan yang cukup cepat $(19,29 \% ; 20,44 \%$; dan $20,33 \%)$.

Nilai tertinggi protein kasar mencapai 27,04\% pada waktu fermentasi 96 jam $\left(\mathrm{P}_{4}\right)$, hal ini karena pada waktu fermentasi 96 jam sesuai kurva pertumbuhan Aspergillus oryzae berada pada fase puncak yaitu hari ketiga dan keempat fermentasi, pertumbuhan pada fase ini merupakan fase maksimum. Dilihat berdasarkan fase pertumbuhan Aspergillus oryzae peningkatan nilai kandungan PK perlakuan $\mathrm{P}_{2}$ terjadi peningkatan 10 kali dari perlakuan $\mathrm{P}_{0}$ dan perlakuan $\mathrm{P}_{3}$ terjadi peningkatan hingga 12 kali dari perlakuan $\mathrm{P}_{0}$. Menurut Sardjono (2008), hari ketiga pada fase pertumbuhan Aspergillus oryzae adalah fase eksponensial yang ditandai dengan kenaikan massa sel dari Aspergillus oryzae secara signifikan. Keadaan ini mengidentifikasikan bahwa pada range waktu tersebut Aspergillus oryzae membelah dengan cepat.

\section{Pengaruh perlakuan kandungan serat kasar (SK) \\ terhadap}

Hasil analisis statistik pada Tabel 3. menunjukkan bahwa perlakuan fermentasi yang bervariasi memberikan hasil berbeda sangat nyata $(\mathrm{P} \leq 0,01)$ terhadap kandungan serat kasar fermentasi ampas putak. Hasil uji Jarak Berganda Duncan memberikan hasil bahwa kandungan serat kasar terendah adalah perlakuan $\mathrm{P}_{0}$ berbeda sangat nyata $(\mathrm{P} \leq 0,01)$ dibandingkan perlakuan lainnya. Perlakuan $\mathrm{P}_{4}$ memiliki kandungan serat kasar tertinggi dan berbeda sangat nyata $(\mathrm{P} \leq 0,01)$ terhadap semua perlakuan. Kandungan serat kasar pada fermentasi ampas putak mengalami peningkatan.

Kandungan SK pada ampas putak tanpa fermentasi $\left(\mathrm{P}_{0}\right)$ memiliki rataan nilai SK terendah yaitu $7,38 \%$ dibandingkan dengan ampas putak perlakuan fermentasi 24 jam $\left(\mathrm{P}_{1}\right), 48$ jam $\left(\mathrm{P}_{2}\right), 72$ jam $\left(\mathrm{P}_{3}\right)$ dan 96 jam $\left(\mathrm{P}_{4}\right)$ yang memiliki rataan nilai $\mathrm{SK}$ sebesar 8,59; 15,14; 19,22; dan 17,28\%. Peningkatan nilai SK diduga karena pertumbuhan Aspergillus oryzae yang diiringi dengan produksi miselium, sehingga terjadi kenaikan kandungan SK ampas putak. Hal ini didukung oleh pendapat Mirwandhono dkk., (2006) bahwa terjadinya peningkatan kandungan SK saat fermentasi disebabkan oleh dinding sel miselia kapang yang mengandung selulosa. Dinding sel kapang selama fermentasi mengalami kumulasi dalam media.

Semakin lama waktu fermentasi maka akan menghasilkan pertumbuhan miselium yang lebat. Secara umum pertumbuhan miselium kapang mempengaruhi kandungan SK produk fermentasi. Berdasarkan hasil penelitian Susanti (2015) terhadap fermentasi ampas kelapa menggunakan kultur Aspergillus oryzae mengalami peningkatan nilai SK dengan lama waktu fermentasi 24 jam, 48 jam, 72 jam dan 96 jam memiliki kandungan SK sebesar 7,35\%; 
9,02\%; 8,85\%; dan 9,95\%. Peningkatan kandungan SK juga dapat diduga karena faktor rendahnya kandungan SK substrat sebelum difermentasi, diketahui bahwa ampas putak tanpa fermentasi memiliki kandungan SK yang rendah yaitu 7,38\% sehingga kondisi ini diduga belum memacu aktifitas enzim selulase dari Aspergillus oryzae untuk merombak SK meskipun pertumbuhan biomassa Aspergillus oryzae lebih tinggi. Hal ini didukung oleh hasil penelitian Nurhayati dkk., (2006) bahwa kandungan SK onggok sebelum fermentasi yaitu $14,54 \%$ setelah fermentasi mengalami kenaikan kandungan SK sebesar 15,45\%, sedangkan pada bungkil inti sawit yang memiliki kandungan SK sebesar 18,50\% mengalami penurunan setelah difermentasi yaitu $17,30 \%$. Hal ini juga terjadi pada tempe yang difermentasi. Kandungan serat kasar tempe setelah difermentasi mengalami kenaikan dari 3,70\% menjadi 5,85\%.

Terjadi penurunan kandungan SK pada fermentasi hari keempat $\left(\mathrm{P}_{4}\right)$ yaitu sebesar $17,28 \%$, hal ini diduga karena hari keempat pada fase pertumbuhan Aspergillus oryzae merupakan fase stasioner yaitu masa laju pertumbuhan bakteri menuju kematian sehingga jumlah bakteri secara keseluruhan tetap. Menurut Sardjono (2008), pada fase pertumbuhan Aspergillus oryzae hari keempat merupakan fase stationer, sehingga ampas putak pada fermentasi 24, 48 dan 72 jam mengalami peningkatan kandungan SK dan terjadi penurunan pada fermentasi 96 jam $\left(\mathrm{P}_{4}\right)$.

Diketahui bahwa sebelum terjadi penurunan pada perlakuan $\mathrm{P}_{4}$ (fermentasi 96 jam) terjadi kenaikan kandungan SK yang cukup tinggi yaitu dua kali dari kandungan SK $\mathrm{P}_{0}$ tanpa fermentasi pada perlakuan $\mathrm{P}_{2}$ (fermentasi 48 jam) sebesar $15,14 \%$ dan kenaikan tiga kali dari kandungan $\mathrm{SK} \mathrm{P}_{0}$ pada perlakuan $\mathrm{P}_{3}$ (fermentasi 72 jam) sebesar 19,22\%. Menurut Sardjono (2008), hari ketiga pada fase pertumbuhan Aspergillus oryzae adalah fase eksponensial yang ditandai dengan kenaikan massa sel dari Aspergillus oryzae secara signifikan. Keadaan ini mengidentifikasikan bahwa pada range waktu tersebut Aspergillus oryzae membelah dengan cepat. Hal ini didukung oleh pendapat Nurhayati dkk., (2006) bahwa pertumbuhan sel kapang yang lebih aktif akan mengakibatkan kenaikan kandungan SK dinding sel kapang. Bahkan pertumbuhan biomassa kapang yang tinggi dapat meningkatkan kandungan SK.

\section{KESIMPULAN}

Berdasarkan hasil penelitian didapatkan kesimpulan sebagai berikut :

1. Lama fermentasi pada ampas putak menggunakan Aspergillus oryzae 0,9\% dapat meningkatkan kualitas fisik. Perlakuan $\mathrm{P}_{4} \quad$ (fermentasi 96 jam) menunjukkan hasil terbaik dengan nilai pH 5,06, warna coklat kehijauan, aroma apek dan tekstur empuk.

2. Lama fermentasi pada ampas putak menggunakan Aspergillus oryzae 0,9\% dapat meningkatkan kandungan nutrien. Perlakuan $\mathrm{P}_{4}$ (fermentasi 96 jam) menunjukkan hasil terbaik dengan kandungan BK 27,75\%, BO 86,72\%, PK 27,04\% dan SK 17,28\%.

\section{SARAN}

Saran yang diberikan dari penelitian ini adalah :

1. Lama fermentasi 96 jam pada ampas putak dengan Aspergillus oryzae 0,9\% menjadi rekomendasi pakan ternak ruminansia karena ditinjau dari kandungan PK dan SK yang tinggi.

2. Perlu dilakukan penelitian lebih lanjut terhadap penampilan ternak.

\section{DAFTAR PUSTAKA}

Abdelhadi, L., Santini, F., \& Gagliostro, G. (2005). Corn silage or high moisture corn supplements for beef heifers grazing temperate pastures: effects on performance, ruminal fermentation and in situ pasture digestion. Animal Feed Science and Technology, 118(1-2), 63-78. https://doi.org/10.1016/J.ANIFEEDSCI.2004.09.007 
Anggraeny, Y. N., \& Umiyasih, U. (2009). Pengaruh Fermentasi Saccharomyces cerevisiae Terhadap Kandungan Nutrisi dan Kecernaan Ampas Pati Aren (Arenga pinnata MERR.). seminar Nasional Teknologi Peternakan dan Veteriner.

Anonimous. (2017). Manfaatkan Isi Batang Pohon Gewang. Malang: Dosen Undana Peroleh Gelar Doktordi Fakultas Peternakan, Universitas Brawijaya.

Eko, D. P., Junus, M., \& Nasich, M. (2013). Pengaruh penambahan urea terhadap kandungan protein kasar dan serat kasar padatan lumpur organik unit gas bio. Repositori UB.

Fuah, A. M., \& Pattie, W. A. (2014). The response of local and verenigde deutch lanvarken pigs to corypha gebanga feeding supplementation. Jurnal Veteriner , 15(4), 557-563.

Gozan, M., Samsuri, M., Siti, F. H., Bambang, P., \& Nasikin, M. (2007). Sakarifikasi dan fermentasi bagas menjadi ethanol menggunakan enzim selulase dan enzim sellobiase. Jurnal Teknologi 3, 3(21), 209-125.

Hastuti, D., Nur, S. A., \& Iskandar, B. M. (2011). Pengaruh perlakuan teknologi amofer (amoniasi fermentasi) pada limbah tongkol jagung sebagai alternatif pakan berkualitas ternak ruminansia. MEDIAGRO, 7(1), 55-65.

Herliani, Sulaiman, A., \& Rahman, Z. (2014). Kualitas nutrisi dan fisik dedak padi yang difermentasi dengan menggunakan ragi tape sebagai bahan pakan itik alabio. Agroscientiae, 21(1), 37-41.
Hidayat, N. (2014). Karakteristik dan kualitas silase rumput raja menggunakan berbagai sumber dan tingkat penambahan karbohidrat fermentable. Agripet, 14(1), 42-49.

Hilakore, M. A. (2008). Peningkatan Kualitas Nutritif Putak Melalui Fermentasi Campuran Trichoderma reesei dan Aspergillus niger Sebagai Pakan Ruminansia. Institut Pertanian Bogor: Tesis. Sekolah Pasca Sarjana.

Hilakore, M. A., Suryahadi, Wiryawan, K., \& Mangunwijaya, D. (2013). Peningkatan kadar protein putak melalui fermentasi oleh kapang trichordema reesei. Jurnal Veteriner, 14(2), 250-254.

Jayanti, D. (2013). Isolasi, karakterisasi, dan amobilisas $\alpha$-amilase dari aspergillus oryzae FNCC 6004. Chem Info Journal, 1(1), 76-84.

Julendra, H., Damayanti, E., Sofyan, A., \& Febrisiantosa, A. (2007). Karakteristik fisiko-kimia dan mikrobiologis pakan berbahan dasar onggok fermentasi selama penyimpanan. Jurnal Sains MIPA, 13(1), 1-5.

Kurnianingtyas, I. B., Pandansari, P. R., Astuti, I., Widyawati, S. D., \& Suprayogi. (2012). Pengaruh macam ekselator terhadap kualitas fisik, kimiawi dan biologis silase rumput kolonjoro. Jurnal Tropical Animal Husbandry, 1(1), 7-14.

Kurniawan, H. (2016). Kualitas nutrisi ampas kelapa (Cocos nucifera L.) fermentasi menggunakan aspergillus niger. Buletin Peternakan, 40(1), 26-33. https://doi.org/10.21059/buletinpeternak.v40i1.9822 
Lamid, M., Ismudiono, Koesnoto, Chusniati, S., \& Vania. (2012). Karakteristik silase pucuk tebu (saccharum officinarum, linn) dengan penambahan lactobacillus plantarum. Jurnal Agroveteriner, 1(1), 1-10.

Lestari, S. (2001). Pengaruh Kadar Ampas Tahu yang Difermentasi Terhadap Efisiensi Pakan dan Pertumbuhan Ikan Mas (Cyprinus carpio). Institut Pertanian Bogor: Skripsi.

Martaguri, I., Mirnawati, M., \& Muis, H. (2011). Peningkatan kualitas ampas sagu melalui fermentasi sebagai bahan pakan ternak. Jurnal Peternakan, 8(1), 38-43. https://doi.org/10.24014/JUPET.V8I1.206

Mirwandhono, E., Bachari, I., \& Situmorang, D. (2006). Uji nilai nutrisi ubi kayu yang difermentasi dengan aspergillus niger. Jurnal Agribisnis Peternakan, 2(1), 91-96.

Miskiyah, Mulyawati, I., \& Haliza, W. (2006). Pemanfaatan Ampas Kelapa Limbah pengolahan Minyak Kelapa Murni Menjadi Pakan. Seminar Nasional Teknologi Peternakan dan Veteriner.

Nurhayati, Sjofjan, O., \& Koentjoko. (2006). Kualitas nutrisi campuran bungkil inti sawit dan onggok yang difermentasi menggunakan aspergillus niger. J. Indon. Trop. Anim. Agric, 31(3), 172-178.

Oramahi, H. A. (2006). Identifikasi jamur genus aspergillus pada gaplek di kabupaten gunung kidul. Jurnal Perlindungan Tanaman Indonesia, 12(1), 25-32.
Rihadini, R. A., Mukodiningsih, S., \& Sumarsih, S. (2017). Kualitas fisik organoleptik limbah tauge kacang hijau yang difermentasi menggunakan trichoderma harzianum dengan level yang berbeda. Jurnal Ilmiah Peternakan Terpadu, 5(2), 28-32. https://doi.org/10.23960/jipt.v5i2.p28-32

Rohmawati, D., Djunaidi, I., \& Widodo, E. (2015). Nilai nutrisi tepung kulit ari kedelai dengan level inokulum ragi tape dan waktu fermentasi berbeda. TERNAK TROPIKA Journal of Tropical Animal Production, 16(1), 30-33. https://doi.org/10.21776/ub.jtapro.2015.016.01.5

Sardjono, S. (2012). Kinetika pertumbuhan aspergillus oryzae KKB4 pada substrat padat serta aktivitas enzim kasar ekstraseluler untuk mereduksi aflatoksin B. AgriTECH, 28(4), 145-149. https://doi.org/10.22146/agritech.9785

Sariri, A. K., Soegiarti, A., \& Sugiyanto. (2011). Peningkatan Nutrien Silage Pennisetum purpureum dengan Penambahan Berbagai Konsentrat Asam Formiat. Seminar Hasil Penelitian dan Pengabdian Kepada Masyarakat.

Soares, D. (2018). Pengaruh Jenis Inokulum Aspergillus niger, Saccharomyces cerevisiae dan Lama Fermentasi Terhadap Komposisi Nutrisi Ampas Putak (Corypha gebanga) dan Aplikasinya Sebagai Pakan Ayam Pedaging. Malang: Tesis. Fakultas Peternakan. Universitas Brawijaya.

Steel, R. G., \& Torrie, J. H. (2003). Prinsip dan Prosedur Statistik, suatu Pendekatan Geometri. Jakarta: Gramedia. 
Sukma, L. N., Zackiyah, \& Gumilar, G. G. (2010). Pengkayaan asam lemak tak jenuh pada bekatul dengan cara fermentasi padat menggunakan aspergillus terreus. Jurnal Sains Dan Teknologi Kimia , 1(1), 66-72.

Susanti, E. D. (2015). Nilai Zat Makanan Hasil Fermentasi Ampas Kelapa (Cocos nucifera L.) Menggunakan Aspergillus oryzae dengan Waktu Fermentasi yang Berbeda. Malang: Skripsi. Universitas Brawijaya.
Winarno, F. G., \& Fardiaz, D. (2000). Pengantar Teknologi Pangan. Jakarta: Gramedia. 